\title{
Validasi Pengukuran Turbiditas dan Material Padatan Tersuspensi di Banjir Kanal Barat, Semarang dengan Menggunakan Smartphone
}

\author{
Irsyad Abdi Pratama ${ }^{1 *}$, Hariyadi Hariyadi ${ }^{1}$, Anindya Wirasatriya ${ }^{1}$, Lilik \\ Maslukah ${ }^{1}$ dan Muh. Yusuf ${ }^{1}$ \\ ${ }^{1}$ Departemen Oseanografi, Fakultas Perikanan dan Ilmu Kelautan, Universitas \\ Diponegoro Jl. Prof. H. Sudarto, S.H., Tembalang, Semarang 50275 Telp/Fax \\ (024)7474698 \\ Email: *irsyadabdipratama131@gmail.com
}

\begin{abstract}
Abstrak
Muara sungai merupakan perairan pantai dimana terjadi tempat pertemuan antara air tawar yang berasal dari daratan dan air laut yang dipengaruhi oleh pasang surut dan gelombang.Aliran sungai yang bermuara di laut membawa material padatan tersuspensi (MPT).Sepanjang aliran sungai Banjir Kanal Barat terdapat kegiatan pemanfaatan ruang seperti industri dan aktifitas pemukiman yang berperan besar sebagai pemasok material padatan tersuspensi di muara sungai Banjir Kanal Barat.Hydrocolor merupakan aplikasi ponsel dengan menggunakan kamera digital ponsel sebagai radiometer 3-band dan sensor auxilary ponsel digunakan untuk mengukur reflektansi pengindraan jauh dari kolom perairan.Data primer meliputi data turbiditas dan data sedimen tersuspensi sebanyak 105 stasiun dan data hydrocolor. Data pendukung yang digunakan yaitu data peta Rupa Bumi Indonesia Skala 1:25.000 Tahun 2018 yang diperoleh dari Badan Informasi Geospasial (BIG). Metode penelitian yang digunakan adalah metode kuantitatif dan metode ekploratif. Hasil penelitian menunjukkan bahwa hubungan data turbiditas lapangan dengan data hydrocolor ditunjukkan oleh nilai bias dan RMSE pada musim sebesar 1,99 NTU dan 5,618 NTU dan musim barat nilai bias dan RMSE sebesar 2,23 NTU dan 3,968 NTU. Algoritma baru dibangun dengan rumus Turbiditas $(\mathrm{NTU})=0.786 \ln (\mathrm{x})+1.5674$ dimana $\mathrm{x}$ adalah nilai turbiditas orisinil dari pengukuran hydrocolor. Turbiditas dengan algoritma baru ini memilki nilai bias dan RMSE sebesar 0,005 NTU dan 0,2957 NTU. Hasil pengolahan data MPT lapangan dengan data hydrocolor, nilai bias dan RMSE pada musim timur sebesar $-38,1 \mathrm{mg} / \mathrm{l}$ dan $39,103 \mathrm{mg} / \mathrm{l}$ dan musim barat nilai bias dan RMSE sebesar $-46,54$ $\mathrm{mg} / \mathrm{l}$ dan 48,581 mg/l.
\end{abstract}

Katakunci:Sedimen Tersuspensi, Turbiditas, Hydrocolor.

\begin{abstract}
River estuaries are parts of coastal waters where the freshwater originating from land and sea water which is influenced by tides and waves meet. River flow that empties into the sea will carry suspended particulate materials (SPM) Along the West Banjir Kanal river, there's spatial use activities such as industry and residential activities which play a major role as a supplier of suspended solids at the mouth of the West Banjir Kanal river. Hydrocolor is a mobile application that uses a mobile digital camera as a 3-band radiometer and a mobile auxilary sensor is used to measure the remote sensing reflectance of the water column. Primary data includes turbidity data and suspended sediment data, which were sampled in the field as many as 105 stations and hydrocolor data. Supporting data used for this research is Indonesia Earth Map Scale 1: 25,000 in 2018 was obtained from the Geospatial Information Agency (BIG). The research method used is the quantitative method and the exploratory method. The results showthe relationship between field turbidity data and hydrocolor data.The bias and RMSE values in the east monsoon were 1.99 NTU and 5.618 NTU and during the west monsoon, the values of bias and RMSE were $2.23 \mathrm{NTU}$ and 3,968 NTU. The new algorithm was built with the formula Turbidity $(N T U)=0.786 \ln (x)+1.5674$, with $x$ is original turbidity value from ydrocolor. The obtained bias and RMSE values of turbidity using new algorithm becomes 0.005 NTU and 0.2957 $N T U$, respectively. The results of field MPT data processing with hydrocolor data, bias and RMSE values in the east monsoon are $-38.1 \mathrm{mg} / \mathrm{l}$ and $39.103 \mathrm{mg} / \mathrm{l}$ and the west monsoon values of bias and RMSE are $-46.54 \mathrm{mg} / \mathrm{l}$ and $48.581 \mathrm{mg} / \mathrm{l}$.
\end{abstract}

Keyword:Suspended sediment, Turbidity, Hydrocolo 


\section{PENDAHULUAN}

Muara sungai merupakan perairan pantai dimana terjadi tempat pertemuan antara air tawar yang berasal dari daratan dan air laut yang dipengaruhi oleh pasang surut dan gelombang (Satriadi, 2004). Aliran sungai yang bermuara di laut akan membawa material padatan tersuspensi (MPT). Material padatan tersupensi (MPT) merupakan material zat padat maupun partikel yang memiliki ukuran lebih dari $1 \mu \mathrm{m}$ yang tersuspensi didalam air. Material padata tersuspensi yang berada di perairan meliputi pasir, lumpur dan tanah liat yang berasal dari daratan yang di transport melalui aliran sungai, udara dan dari dalam laut itu sendiri. Material padatan tersuspensi merupakan salah satu faktor utama penyebab terjadinya sedimentasi di daerah muara sungai (Taohid, 2017)

Untuk mengetahui sebaran MPT umumnya diperoleh melalui pengambilan sampel air secara langsung di lokasi tersebut yang dilanjutkan dengan analisis laboratorium. Namun metode tersebut memiliki kelemahan yaitu kurangnya efesiensi waktu dan biaya. Zaman modern saat ini beberapa teknologi sudah dilengkapi dengan beberapa sensor, khusus nya untuk smartphone. Teknologi smartphone juga dapat diaplikasikan untuk memperkirakan kondisi MPT di lapangan.

Smartphone merupakan perangkat seluler yang dilengkapi dengan sistem operasi layaknya komputer. Smartphone dapat mengimplementasikan berbagai bentuk multimedia (Ismanto,2017).Smartphone sudah ada banyak dipakai oleh berbagai kalangan dan menjadi semakin lebih canggih dengan komputasi, jaringan, dan kekuatan penginderaan yang terus berkembang. Hal ini telah mengubah pandangan orang-orang terhadap kebutuhan sehari-hari dan telah membuka berbagai variasi bagi banyak data aplikasi yang menarik, mulai dari kesehatan dan pemantauan kebugaran, komputasi perkotaan, teknologi pendukung, dan perawatan lansia, hingga lokalisasi dalam ruangan dan navigasi, dan lain-lain (Su, 2014). Salah satu aplikasi yang bisa digunakan untuk mengukur MPT di perairan yaitu aplikasi yan bernama hydrocolor.

Hydrocolor merupakan aplikasi ponsel dengan menggunakan kamera digital ponsel sebagai radiometer 3-band dan sensor auxilary ponsel digunakan untuk mengukur reflektansi pengindraan jauh dari kolom perairan. Aplikasi tersebut dapat mengumpulkan urutan dari tiga citra. Gambar citra tersebut digunakan untuk mengukur reflektansi pengindraan jauh dalam band gelombang merah, hijau dan biru.

Penelitian terkait mengenai kekeruhan sebelumnya telah dilakukan oleh Suhendar pada tahun 2020 di daerah tambak udang dengan menggunakan aplikasi hydrocolor. Akan tetapi dalam penelitian tersebut tidak melakukan uji akurasi terhadap data sampel air langsung dan sampel penelitian terlalu sedikit, maka dari itu dalam penelitian ini akan menguji akurasi aplikasi hydrocolor di area pesisir pantai dengan sampel yang cukup banyak.

Penelitian ini dilakukan untuk mengetahui konsentrasi turbiditas dan MPT di sekitar lokasi penelitian dengan menggunakan kombinasi metode berbeda yaitu, observasi lapangan dan aplikasi berbasis smartphone yaitu hydrocolor. Selanjutnya dilakukan uji validasi nilai turbiditas dan MPT hasil pengukuran hydrocolor dengan hasil pengukuran lapangan.

\section{MATERI DAN METODE}

Materi penelitian yang digunakan dalam penelitian ini meliputi data utama dan data penunjang. Data utama yang digunakan adalah data yang diperoleh dari hasil pengukuran selama pengambilan sampel. Data utama meliputi data turbiditas dan data sedimen tersuspensi dilakukan pengambilan sampel di lapangan sebanyak 105 stasiun (Gambar 1) pada musim timur (Agustus 2020) dan barat (April 2020). Sedangkan data pendukung yang digunakan adalah peta Rupa Bumi Indonesia Skala 1:25.000 Tahun 2018 yang diperoleh dari Badan Informasi Geospasial (BIG).

Metode penelitian yang digunakan adalah metode kuantitatif dan metode ekploratif. Metode kuantiatif menurut Sugiyono (2009) data penelitian berupa angka-angka dan dianalisis secara statistik. Metode ini bertujuan untuk menggambarkan keadaan distribusi padatan tersuspensi di perairan muara Banjir Kanal Barat.Metode penentuan titik sampling ini menggunakan purposive sampling methode.Penentuan lokasi pengambilan sampel penelitian dilakukan berdasarkan kondisi yang diharapkan dapat mewakili kondisi secara keseluruhan 
daerah yang diteliti. Stasiun 1 sampai 24 diharapkan mewakili muara sungai, kemudian stasiun 25 sampai 65 mewakili perairan yang masih dipengaruhi oleh muara, sedangkan stasiun 66 sampai 100 mewakili laut lepas.

Pengukuran sampel turbiditas menggunakan Turbidity Meter pada 105 stasiun pengamatan. Pengukuran turbiditasdiambil dengan kedalaman kurang dari 1 meter pada saat surut. Teknik pengambilan seperti ini disebut sebagai teknik pengukuran langsung atau direct sampling.

Sampel sedimen tersuspensi diambil menggunakan botol nansen yang bertujuan untuk mengetahui konsentrasi material padatan tersuspensi yang ada di wilayah tersebut (Poerbandono dan Djunasjah, 2005). Perhitungan nilai konsentrasi sedimen tersuspensi dilakukan dengan uji laboratorium sesuai SNI 06-6989.3-20004 secara gravimetri (SNI M-03-1990 F).

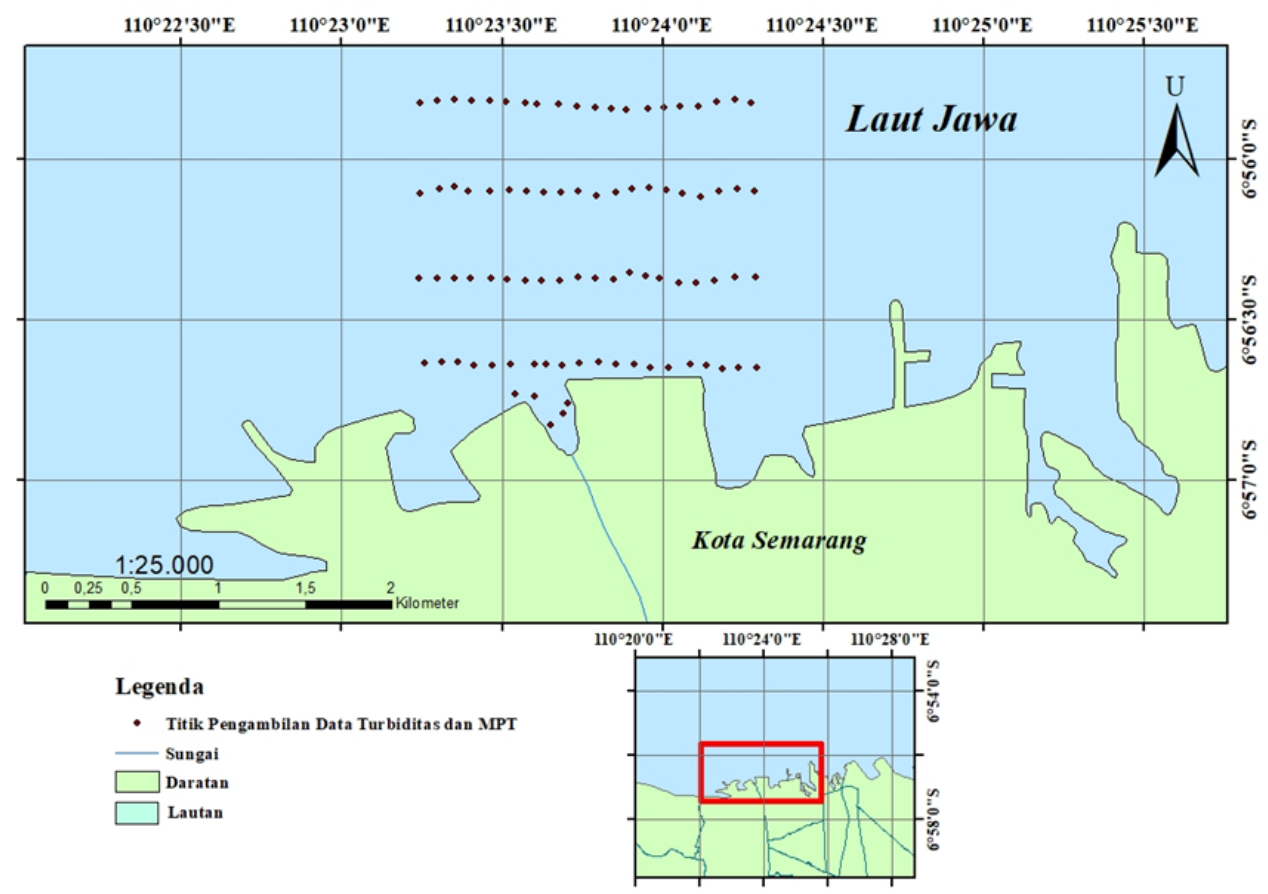

Gambar 1. Peta Lokasi Stasiun Pengambilan Sampel Turbiditas dan MPT

Pengukuran turbiditas dan MPT dengan aplikasi hydrocolor mengikuti Leeuw dan Boss (2018).Pengolahan data hydrocolor umumnya merupakan data mentah (raw data), sehingga perlu dilakukan pengolahan secara digital.Pengolahan data hydrocolor bertujuan untuk menentukan nilai MPT dan turbiditas dimana data tersebut masih berupa beberapa nilai reflektan.Data yang telah diperoleh dari lapangan berupa data material padatan tersuspensi (MPT) dan turbidity. Data tersebut diolah dengan menggunakan beberapa algoritma yang telah di buat oleh Leeuw dan Boss (2018), dengan algoritma yang digunakan sebagai berikut :

- Remote Sensing Reflektan

- Turbiditas

$$
\operatorname{Rrs}=\frac{\left(L_{\text {air }}-0,028 L_{\text {langit }}\right)}{\pi / 0,18 l_{\text {kartu }}}
$$

$$
\text { Turbiditas } \left.=\frac{\left(2,77 R r s_{(\text {merah })}\right)}{(0,05-\operatorname{Rrs}(\text { merah })}\right)
$$

- Material Padatan Tersuspensi

$$
\log 10(\text { MPT })=1,02 \log 10(\text { Turbiditas })-0,04
$$

Keterangan:

Lair $=$ Radiasi dari permukaan air

Llangit $=$ Radiasi dari Langit 
Lkartu $=$ Radiasi dari kartu abu-abu

Rrs $($ Merah $)=$ Nilai reflektan kanal merah

Data yang diperoleh melalui aplikasi Hydrocolor dilakukan tahap validasi untuk mengetahui seberapa besar kemiripannya dengan data yang sebenarnya. Validasi data merupakan proses statistik yang berguna untuk mengetahui perbandingan antara data model dengan data lapangan. Perbandingan ini bertujuan untuk mengetahui seberapa besar kemiripan antara data model dengan data lapangan (Allen et al., 2007 dalam Jing et al., 2013). Nilai akurasi data dapat diketahui dengan menghitung seberapa besar error (kesalahan) pada data yang didapat. Nilai kesalahan dapat dihitung dengan rumus bias dan RMSE.

- Root Mean Square Error (RMSE)

$$
\begin{aligned}
& \text { RMSE }=\sqrt{ }\left(\left(\sum_{i=1}^{n} \frac{(x e-x m)^{2}}{n}\right)\right. \\
& \text { Keterangan: } \\
& \text { xm } \quad=\text { Nilai hasil pengukuran lapangan yang dianggap benar } \\
& \mathrm{xe} \quad=\text { Nilai hasil pengolahan } \\
& \mathrm{n} \quad=\text { Jumlah data }
\end{aligned}
$$

Jika, nilai bias dan RMSE menunjukan kesalahan (error) yang besar, maka perlu dilakukan pencarian algoritma baru untuk MPT dan turbiditas berbasis aplikasi Hydrocolor.Penentuan algoritma baru turbiditas dan MPT menggunakan metode regersi.Algoritma dengan Metode Regresi yang selanjutnya disebut dengan algoritma LEL (regresi linear, eksponensial dan logaritmik) menggunakan persamaan yang diperoleh melalui analisis regresi antara nilai MPT atau turbiditas Hydrocolor dengan MPT atau turbiditas hasil pengukuran lapangan dengan operasi matematika sederhana. Persamaan algoritma Metode Regresi diperoleh melalui pendekatan secara linear, eksponensial dan logaritmik. Hasil terbaik dari analisis regresi akan digunakan sebagai algoritma yang mewakili algoritma dengan Metode Regresi.

\section{HASIL DANPEMBAHASAN}

Nilai konsentrasi turbiditas di Muara Banjir Kanal Barat diperoleh melalui uji laboratorium menggunakan instrumen turbiditas Meter. Hasil pengukuran laboratorium pada musim barat menunjukkan bahwa nilai tertinggi terdapat pada stasiun 103 dengan konsentrasi turbiditas sebesar 5,57 NTU, nilai terendah terdapat pada stasiun 79 sebesar 2,03 NTU dan nilai rata-rata yaitu 3,00 NTU. Sedangkan pada musim timur menunjukan bahwa niali tertinggi terdapat pada stasiun 101 dengan konsentrasi turbiditas sebesar 7,71 NTU, nilai terendah terdapat pada stasiun 38 sebesar 0,94 NTU dan nilai rata-ratanya sebesar 2.98 NTU.

Sedangkan untuk data hydrocolor Hasil pengukuran pada musim barat menunjukkan bahwa nilai tertinggi terdapat pada stasiun 3 dengan konsentrasi turbiditas sebesar 22 NTU, nilai terendah terdapat pada stasiun 51, 78 dan 80 sebesar 2 NTU dan nilai rata-rata yaitu 6,17 NTU. Sedangkan pada musim timur menunjukan bahwa niali tertinggi terdapat pada stasiun 14 dengan konsentrasi turbiditas sebesar 34 NTU, nilai terendah terdapat pada stasiun 64 sebesar 1 NTU dan nilai rataratanya sebesar 5,44 NTU.

Berdasarkan dari hasil pengambilan data antara data lapangan dengan data hydrocolor yang diambil pada musim barat dan musim timur, dilakukan uji akurasi data.Hasil uji akurasi yang diperoleh yaitu pada musim barat memiliki nilai bias sebesar -2,23 dan RMSE 3,968. Sedangkan pada musim timur memiliki nilai bias sebesar -1,99 dan nilai RMSE 5,618.Gambaran uji akurasi data tersebut bisa dilihat pada Gambar 2 dan Gambar 3. 


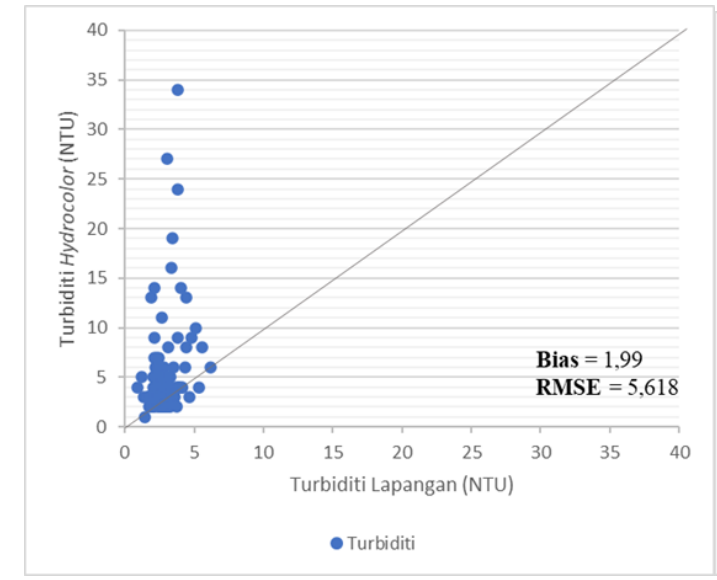

Gambar 2. Grafik Uji Akurasi Turbiditas Hydrocolor dengan Turbiditas Lapangan pada Musim Timur

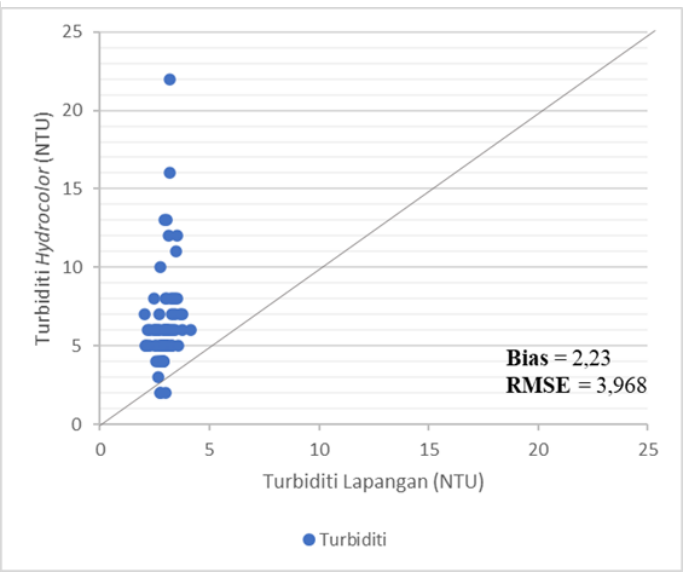

Gambar 3. Grafik Uji Akurasi Turbiditas Hydrocolor dengan Turbiditas Lapangan pada Musim Barat

Berdasarkan Gambar 2 dan Gambar 3, data turbiditas antara data lapangan dan data hydrocolor itu memiliki nilai bias dan RMSE yang cukup tinggi. Pada musim timur nilai bias sebesar 1,99 dan RMSE 5,618. Sedangkan pada musim barat nilai bias sebesar 2,33 dan RMSE 3,968. Besarnya nilai bias dan RMSE ini membuat data hydrocolor cenderung overestimated sehingga akurasi kurang bagus, maka dari itu diperlukan algoritma baru untuk menyesuaikan datanya

Algoritma baru dibangun berdasarkan nilai yang diperoleh dari hasil uji laboratorium dan hasil dari aplikasi hydrocolor yang diambil pada musim barat dan musim timur. Gambar 4. Menunjukan bahwa nilai koefisien determinasi $\left(\mathrm{R}^{2}\right)$ pada musim timur dengan nilai yang diperoleh langsung dari aplikasi hydrocolor sebesar 0,3831 dan Gambar 5menunjukan bahwa nilai koefisien determinasi $\left(\mathrm{R}^{2}\right)$ pada musim barat dengan nilai yang diperoleh langsung dari aplikasi hydrocolor memiliki nilai korelasi sebesar 0,7046

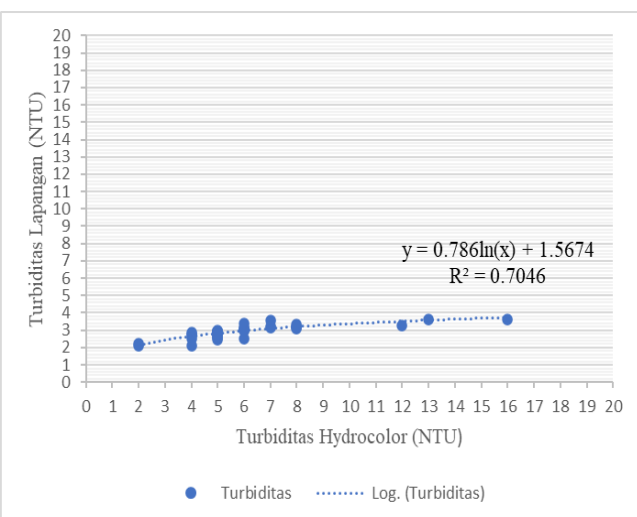

Gambar 4. Grafik Hubungan antara Turbiditas Hydrocolor dengan Turbiditas Lapangan pada Musim Timur

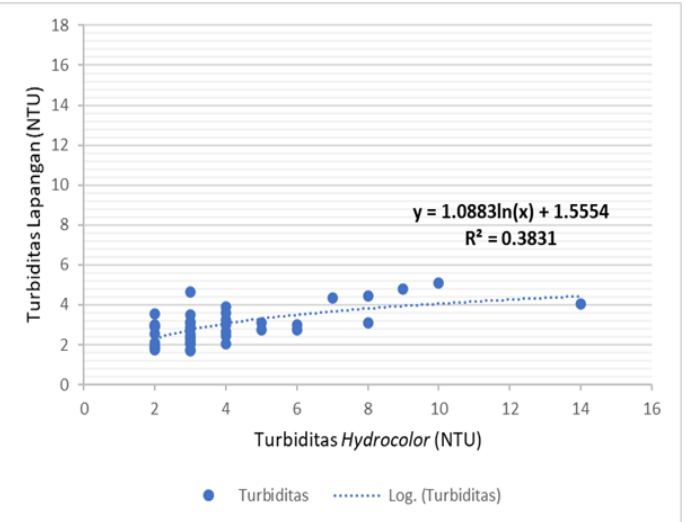

Gambar 5. Grafik Hubungan antara Turbiditas Hydrocolor dengan Turbiditas Lapangan pada Musim Barat 
Berdasarkan Berdasarkan hasil pengolahan pada kedua musim, musim barat memiliki nilai koefisien determinasi tertinggi maka dari itu musim barat digunakan untuk membangun algorotima baru. Data yang digunakan sebanuak 40 stasiun yang digunakan untuk generate algoritma baru dan 49 stasiun digunakan sebagai validasi yang akan dicantumkan pada Gambar 6.Berdasarkan persamaan logaritmik antara nilai Turbiditas hydrocolor dengan nilai konsentrasi data lapangan pada musim barat menghasilkan koefisien persamaan algoritma Turbiditas yang baru. Algoritma Turbiditas :

$$
\text { Turbiditas }(\mathrm{NTU})=0.786 \ln (\mathrm{x})+1.5674
$$

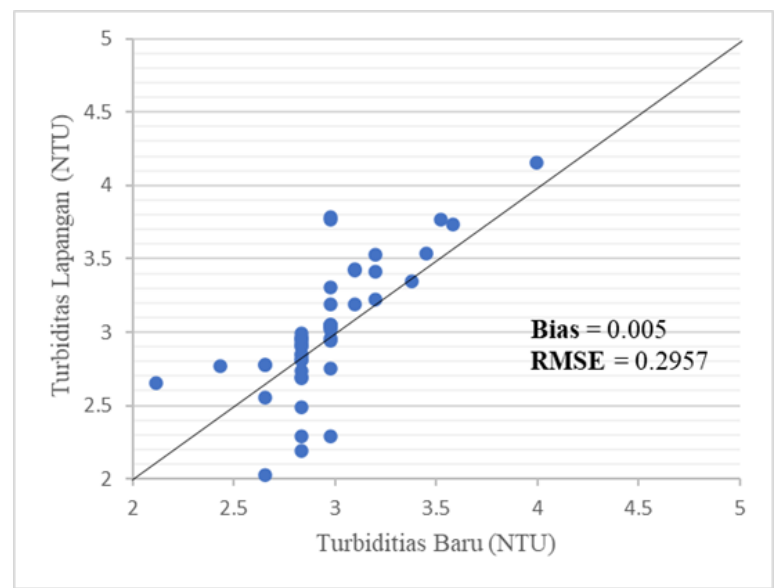

Gambar 6. Grafik Validasi Turbiditas Hydrocoloralgoritma baru dengan Turbiditas Lapangan

Hasil uji validasi nilai turbiditas dengan algoritma regresi baru menunjukan bahwa nilai bias dari hasil tersbut sebesar 0,055 dengan nilai RMSE sebesar 0,2957.

Berdasarkan dari hasil pengambilan data MPT antara data lapangan dengan data hydrocolor yang diambil pada musim barat dan musim timur, dilakukan uji akurasi data. Hasil uji akurasi yang diperoleh yaitu pada musim barat memiliki nilai bias sebesar 38,1 dan RMSE memiliki nilai sebesar 39,103. Sedangkan pada musim timur memiliki nilai bias sebesar 46,56 dan nilai RMSE sebesar 48,581. Berdasarkan dari hasil uji akurasi dari kedua musim tersebut terlihat bahwa data hydrocolor memiliki akurasi yang cukup rendah terhadap data lapangan, maka dari itu diperlukan penyesuaian dengan membuat sebuah algoritma baru untuk Turbiditas di Muara Banjir Kanal Barat untuk data hydrocolor.

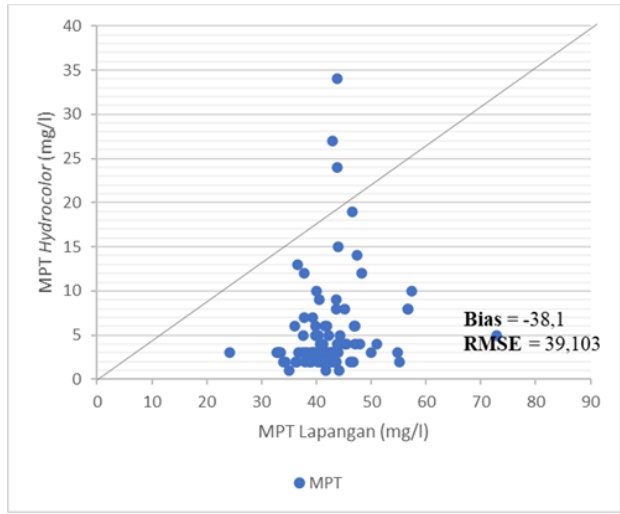

Gambar 7. Grafik Uji Akurasi MPT Hydrocolor dengan MPT Lapangan pada Musim Timur

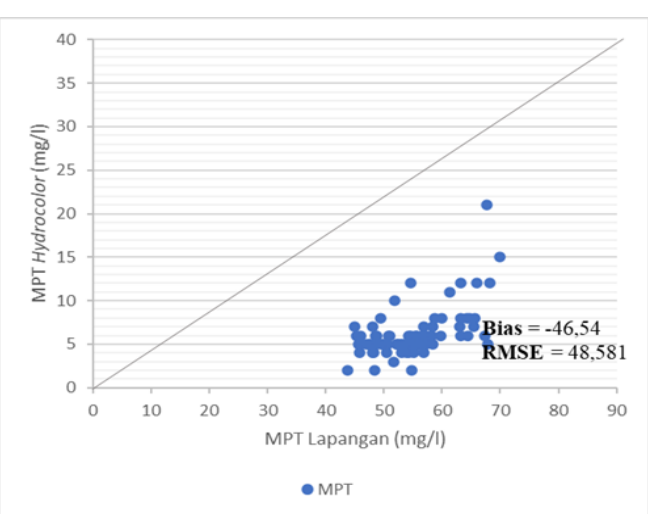

Gambar 8. Grafik Uji Akurasi MPT Hydrocolor dengan MPT Lapangan pada Musim Barat 
Algoritma baru dibangun berdasarkan nilai yang diperoleh dari hasil uji laboratorium dan hasil dari aplikasi hydrocolor yang diambil pada musim barat dan musim timur. Gambar 9menunjukan bahwa nilai koefisien determinasi $\left(\mathrm{R}^{2}\right)$ pada musim timur dengan nilai yang diperoleh langsung dari aplikasi hydrocolor sebesar 0,3911 dan Gambar 10 menunjukan bahwa nilai koefisien determinasi $\left(\mathrm{R}^{2}\right)$ pada musim barat dengan nilai yang diperoleh langsung dari aplikasi hydrocolor memiliki nilai korelasi sebesar 0,3169.

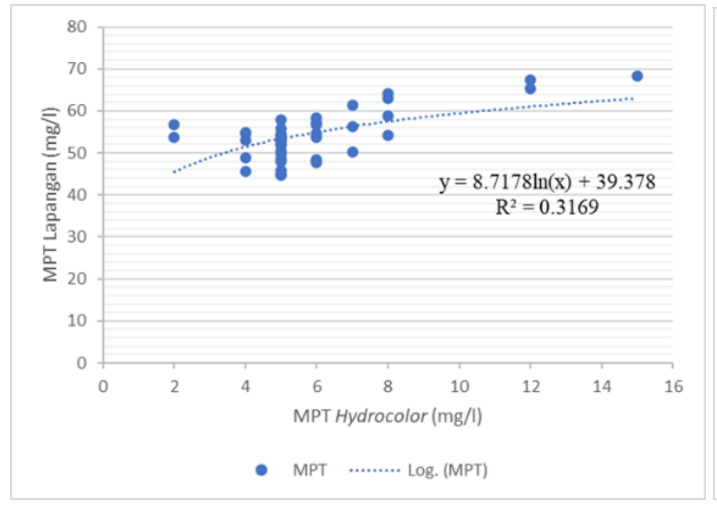

Gambar 9. Grafik Hubungan antara MPT Hydrocolor dengan MPT Lapangan pada Musim Timur

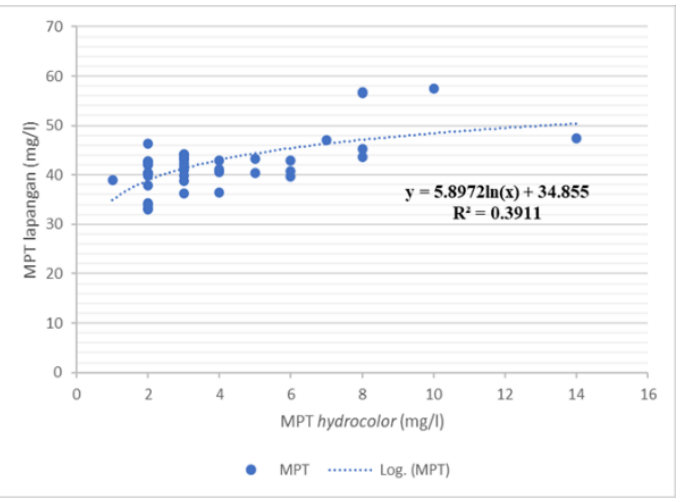

Gambar 10. Grafik hubungan antara MPT Hydrocolor dengan MPT Lapangan pada Musim Barat

Berdasarkan hasil pembuatan algoritma baru, terlihat bahwa nilai koefisien determinasi $\left(\mathrm{R}^{2}\right)$ baik pada musim timur maupun pada musim barat memiliki nilai yang kecil, maka dari itu untuk pembuatan algoritma baru tidak dilanjutkan karena nilai dari koefisien tersebut terlalu kecil yang menggambarkan bahwa nilai MPT hydrocolor dan nilai MPT lapangan memiliki hubungan yang cukup jauh.

Astuti (2017) menerangkan bahwa nilai $\mathrm{R}^{2}$ yang kecil memiliki kemampuan variable independen dalam menjelaskan variabel dependen terbatas, sehingga untuk selanjutnya dalam tahap generate algoritma baru tidak dilanjutkan. Hal ini dipengaruhi oleh persamaan bawaan yang tersedia pada aplikasi tersebut sehingga diperlukan kajian yang lebih dalam lagi dalam penerapan nilai MPT di lapangan khususnya untuk daerah Muara Banjir Kanal Barat. Hasil data yang tidak bagus disebabkan Ketika pengambilan data terjadi, cuaca di daerah Banjir Kanal Barat mengalami mendung, Leeuw and Boss (2018) menerangkan bahwa kondisi cerah merupakan pengambilan data terbaik menggunakan aplikasi hydrocolor karena dapat mempengaruhi nilai perhitungan reflektan dari aplikasi ini. Sehingga banyak data error yang mempengaruhi akurasi data lapangan dengan data hydrocolor.

\section{KESIMPULAN}

Berdasarkan hasil penelitian di lapangan, Hasil analisa turbiditas antara data lapangan dengan data hydrocolor kurang bagus, penerapan algoritma baru diperoleh dari nilai regresi antara data lapangan dengan data hydrocolor. Hasil algoritma baru untuk turbiditas diperoleh dengan persamaan logaritmik. Rumus turbiditasyang diperoleh yaitu : turbiditas (NTU) = $0.786 \ln (\mathrm{x})+1.5674$. Hasil dari penerapan algoritma baru diperoleh dengan nilai bias sebesar 0,055 dengan nilai RMSE $=0,2957$. Sedangkan Hasil analisa MPT antara data lapangan dengan data hydrocolor juga kurang bagus, hali ini terlihat dari nilai bias dan RMSE pada kedua musim terlalu besar. Penerapan algoritma baru untuk MPT tidak dilanjutkan karena nilai $\mathrm{R}^{2}$ pada kedua musim terlalu kecil sehingga tidak memungkinkan untuk mendapatkan akurasi yang bagus. 


\section{DAFTAR PUSTAKA}

Astuti, T.T. Bambang, A.N. dan S. Diah. P. 2017. Analisis Ekonomi Rumah Tangga Nelayan Pandega pada Alat Tangkap Mini Purse Seine di TPI Pelabuhan, Kota Tegal. Journal of Fisheries Resources Utilization Management and Technology, 6(4) : 138-147.

Ismanto, E. Novalia, M dan Herlandy, P.B. 2017. Pemanfaatan Smartphone Android Sebagai Media Pembelajaran Bagi Guru Sma Negeri 2 Kota Pekanbaru. Jurnal Untuk Mu Negeri, 1 (1) : 42-47.

Jing, H., P. Cun-hong, K. Cui-ping, Z. Jian dan C. Gang. 2013. Experimental Hydrodynamic Study of the Qiantang River Tidal Bore. Journal Hydrodynamics. 25(3):481-490.

Leeuw, T., dan Boss, E. 2018. The HydroColor App: Above Water Measurements of Remote Sensing Reflectance and Turbidity Using a Smartphone Camera. Sensors, 18 (1) :256. https://doi.org/10.3390/s18010256

Ongkosongo, O.S.R., dan Suyarso. 1989. Pasang Surut. Lembaga Ilmu Pengetahuan Indonesia, Jakarta.

Poerbandono dan E. Djunasjah. 2005. Survei Hidrologi. PT Refika Aditama, Bandung.

Satriadi, A. dan S. Widada. 2004. Distribusi Muatan Padatan Tersuspensi di Muara Sungai Bodri, Kabupaten Kendal. Jurnal Ilmu Kelautan., 9(2):101-107.

Su, X. Hanghang, T dan Ji, P. 2014. Activity Recognition with Smartphone Sensors. Tsinghua Science And Technology, 19 (3) : 235-249.

Sugiyono. 2009. Metode Penelitian Kuantitatif, Kualitatif, dan R\&D. Alfabeta, Bandung.

Suhendar, D.T. Sachoemar, S.I dan Azam B.Z. 2020. Hubungan Kekeruhan Terhadap Materi Partikulat Tersuspensi (MPT) dan Kekeruhan Terhadap Klorofil dalam Tambak Udang. Journal of Fisheries and Marine Research, 4(3) : 332-338

Sugiyono. 2016. Metode Penelitian Kuantitatif, Kualitatif, dan $R \quad \& \quad D$. Bandung:Alfabeta.

Taohid, R.A.,Satriadi, A.,dan Saputro,S. 2017. Studi Pola Arus Dan SebaranMaterial Padatan Tersuspensi di Pantai Marina Ancol, Jakarta. JurnalOseanografi, 6 (1) : $116-123$. 